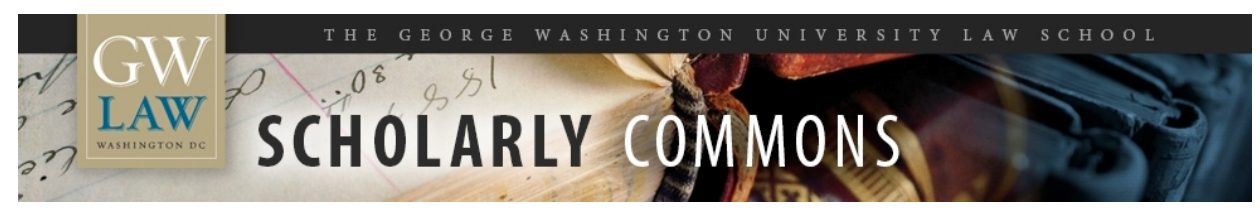

\title{
Beginning Testimony with an Overview Witness
}

Stephen A. Saltzburg

George Washington University Law School, ssaltz@law.gwu.edu

Follow this and additional works at: https://scholarship.law.gwu.edu/faculty_publications

Part of the Law Commons

\section{Recommended Citation}

Saltzburg, Stephen A., Beginning Testimony with an Overview Witness (2012). 27 Crim. Just. (2012) ; GWU Law School Public Law Research Paper No. 2012-154; GWU Legal Studies Research Paper No. 2012-154. Available at SSRN: http://ssrn.com/abstract $=2669934$

This Article is brought to you for free and open access by the Faculty Scholarship at Scholarly Commons. It has been accepted for inclusion in GW Law Faculty Publications \& Other Works by an authorized administrator of Scholarly Commons. For more information, please contact spagel@law.gwu.edu. 


\section{Beginning Testimony with an Overview Witness BY STEPHEN A. SALTZBURG}

$\mathrm{I}$ n a criminal case of any complexity, lawyers are reasonably concerned about whether jurors will understand the evidence. Prosecutors may have an even greater concern than defense counsel in some cases because they bear a heavy burden of proof, and confusion among jurors may make it more difficult for prosecutors to prove guilt beyond a reasonable doubt. There are various ways that experienced lawyers endeavor to make complicated matters more understandable to jurors. They use visual evidence, summary charts of voluminous evidence under rules such as Federal Rule of Evidence 1006, prepare transcripts to assist in comprehending recorded conversations, offer expert testimony to explain unfamiliar concepts and terms, and sometimes ask trial judges to admit pedagogical summaries under rules like Federal Rule of Evidence 611(a) or 1006. In recent years, prosecutors have found the use of an introductory witness to set forth an outline of their cases to be an effective advocacy tool. Some courts have found it to be too effective.

\section{An Illustrative Case}

In United States v. Moore, 651 F.3d 30 (D.C. Cir. 2011), the United States Court of Appeals for the District of Columbia reviewed the convictions of six defendants who, along with others charged and tried separately, were charged with conducting and conspiring to conduct a drug distribution business during the 1980s and 1990s in Washington, D.C. The government alleged that the business involved considerable violence, including 31 murders. The trial lasted 10 months before the jury found the



STEPHEN A. SALTZBURG, a past chair of the Criminal Justice Section, is the Wallace and Beverley Woodbury University Professor at George Washington University School of Law in Washington, D.C., and contributing editor to Criminal Justice magazine. He is also author of the book, Trial Tactics, Second Edition (American Bar Association 2009), an updated and expanded compilation of his columns. defendants guilty of the drug conspiracy, a RICO conspiracy, and other crimes. The trial judge sentenced each of the defendants to prison terms that were in excess of life imprisonment.

\section{The Opening Witness}

The defendants raised a host of issues on appeal, but the one that is the focus here is the argument that the defendants were unfairly prejudiced by the prosecution's calling an FBI agent to testify as its first witness in order to provide an overview of the government's case-in-chief. The court observed that its "conclusions are not affected by whether appellants' challenge is viewed as a question of prosecutorial misconduct, as appellants contend, or a claim of abuse of discretion by the district court in admitting inadmissible evidence." (Id. at 55.)

\section{The Only Circuit Precedent: A Summary Witness}

The court had not previously addressed the use of an overview witness but had identified in United States v. Lemire, 720 F.2d 1327, 1348 (D.C. Cir. 1983), the "obvious dangers posed by summarization of evidence" by a nonexpert witness during the government's case-in-chief. In Lemire, the government called an FBI agent, who was a certified public accountant, toward the end of its case-in-chief to summarize the evidence about the complex cash flow through offshore companies in a prosecution for wire fraud, interstate transportation of the proceeds of fraud, and conspiracy. The agent used four summary charts to organize the evidence already presented by the government, and the charts identified the document in evidence from which each item of information was drawn. The defendant objected that the agent lacked personal knowledge as required by Federal Rule of Evidence 602, but the trial judge admitted the agent's testimony as "explanatory" rather than as "substantive" evidence.

\section{Dangers and Advantages of \\ Summary Witnesses}

The court of appeals affirmed in Lemire and recognized "an established tradition" permitting summary evidence to be introduced along with appropriate limiting instructions to the jury. After noting that the evidence was cumulative and subject to challenge under Rule 403, Lemire acknowledged that a nonexpert summary 
witness can help the jury organize and evaluate complex factual evidence that is elicited in fragments through the testimony of many witnesses throughout a trial.

The Lemire opinion strongly suggests that the court was aware of the dangers of summary testimony as well as its advantages. The court concluded that the claim of unfair prejudice raised more troubling concerns than the Rule 602 claim.

Lemire identified three obvious dangers posed by summarization of evidence. First, there is a danger that the jury might treat the summary evidence as additional or corroborative evidence that unfairly strengthens the government's case. Lemire indicated that cross-examination and limiting instructions could guard against this danger.

Second, summary witness testimony poses the risk that otherwise inadmissible evidence might be introduced. Lemire found that on the facts (1st Cir. 2004) (citation omitted):

[S] uch testimony raises the very real specter that the jury verdict could be influenced by statements of fact or credibility assessments in the overview but not in evidence. There is also the possibility that later testimony might be different than what the overview witness assumed; objections could be sustained or the witness could change his or her story. Overview testimony by government agents is especially problematic because juries may place greater weight on evidence perceived to have the imprimatur of the government.

(Moore, 651 F.3d at 57.)

Moore was skeptical of the government argument that an overview witness aids the jury by framing

\section{The jury might treat the summary evidence as additional or corroborative evidence that unfairly strengthens the government's case.}

presented this was not much of a risk because the trial participants heard the agent describe the documents he reviewed to arrive at the summary and thus were well situated to prevent reliance on an erroneous or misleading summary.

Third, a summary witness might permit the government to have more than one closing argument, because the witness might be doing just what the prosecutor does in summation. Lemire found that the agent made no controversial inferences and did not pronounce judgment, and thus was not arguing the way a prosecutor would argue in closing.

\section{The Dangers of an Overview Witness}

Lemire involved a witness whose testimony came at the close of testimony, whereas Moore raised a challenge to the use of an overview witness who testifies at the outset of a case. The Moore court observed that "[o]ther circuits to address the use of overview witnesses have reached uniformly negative conclusions in view of the serious dangers of prejudice to a fair trial. (Moore, 651 F.3d at 56.) It quoted from the First Circuit's opinion in United States v. Casas, 356 F.3d 104, 119-20 how the government's case will unfold, and quoted from the Second Circuit's opinion in United States v. Garcia, 413 F.3d 201, 214 (2d Cir. 2005): "[T] he law already provides an adequate vehicle for the government to 'help' the jury gain an overview of anticipated evidence as well as a preview of its theory of each defendant's culpability: the opening statement." (Moore, 651 F.3d at 57.)

Moore noted that in its decision in United States v. Smith, 640 F.3d 358, 367 (D.C. Cir. 2011) (citations omitted), it had "recently observed that the First, Second, and Fifth Circuits 'have viewed agents' hearsay-laden or hearsay-based overview testimony at the onset of trial as a rather blatant prosecutorial attempt to circumvent hearsay rules."” (Moore, 651 F.3d at 57.)

\section{The Testimony in Moore}

The court found in Moore that all three dangers identified by Lemire were present. In sum, the court concluded as follows: "FBI Agent Sparks testified about evidence not yet presented while opining that the cooperating witnesses would present truthful evidence because they were insiders and were guilty themselves, strengthening 
the government's yet-to-be presented case and offering inadmissible evidence while providing the government with a second opening argument." (Id. at 58.) The court offered examples of the problems presented by Agent Sparks's testimony:

For example, upon being shown a map of the District of Columbia, FBI Agent Sparks confirmed that the 31 circles located on the map accurately reflected the locations of the 31 charged murders, and that murders clustered in certain locations occurred toward the beginning of the charged conspiracy. But no such evidence was before the jury and FBI Agent Sparks did not purport to testify from personal knowledge of each murder. At other points, FBI Agent Sparks referred to witness testimony that was never presented to the jury during the course of the trial. In one exemplary circumstance, FBI Agent Sparks testified on redirect examination that co-conspirator Erskine Hartwell had described his role in the conspiracy as supplying drugs and introducing Moore and Gray to Oscar Veal. When asked by the district court whether this information was "based on what [Hartwell] told [him]," FBI Agent Sparks agreed, prompting the district court to state: "The jury is going to hear his testimony." Yet when asked only moments later by the prosecutor "if Erskine Hartwell will be a witness in this case or not," FBI Agent Sparks replied that he "d[idn't] know for sure if [Hartwell] will." From portions of the transcript submitted by the parties to this court, there is no indication that Hartwell testified at trial and hence "later testimony ... differe[d] [from] what the overview witness assumed."

(Id. at 58-59 (alterations in the original) (citations omitted).)

The court offered another example of testimony by Agent Sparks that it found disturbing:

$[\mathrm{H}] \mathrm{e}$ testified that it was important, in his view, to use cooperating witnesses in this case because it was "the only way" to gain "access to the inside information." Acknowledging that cooperating witnesses were "themselves . . . criminals[,] unfortunately," he further testified that the cooper- ating co-conspirator witnesses nonetheless

know what's going on, they have the information, they're the eyewitnesses, earwitnesses, they hear what these guys are talking about after they commit a murder, they witness a murder, they know where the stash locations are for drugs. ... [T] hey are present when drug deals are done. They have been with these people day in and day out, and you need that kind of testimony. That's the only way to put these kind[s] of cases together.

He also testified that the goal in a debriefing session was to "[g]et[] complete and truthful information" and that it was important to "try and verify" the information "[j] ust to make sure the person is truthful, that they are complete." On redirect examination, FBI Agent Sparks reinforced the notion that the cooperating witnesses were guilty of committing crimes in their capacity as the defendants' co-conspirators:

Q: You were asked a lot of questions on cross-examination about cooperating witnesses, and you continually referred to them as criminals.

A: Yes.

Q: Any doubt in your mind about that?

A: None whatsoever.

(Id. at 59 (alterations in the original) (citations omitted).)

\section{Going Forward}

In Moore, the D.C. Circuit joined other circuits in "condemning the practice" of having the government begin a criminal case with an overview witness. Despite the discretion afforded trial judges to control the mode and order of proof, the court concluded that a trial judge would have difficulty assuring that an overview witness does not provide the government with an unfair advantage:

The use of overview witnesses exacerbates the "obvious dangers" this court identified in Lemire in the use of non-expert summarization evidence. Overview testimony offers an opportunity to "poison the jury's mind against the defendant or to recite items of highly questionable evidence." Avoidance of 
those dangers is largely beyond the ability of the district court, much less the defense, to prevent. As the record here demonstrates, a trained law enforcement officer is likely to go as far as the questions allow, presenting a picture for the jury of a solid prosecution case based on his opinion of the strength and credibility of the witnesses the government plans to call to testify at trial for reasons made persuasive in view of the officer's training and experience.

(Id. at 60 (citation omitted).)

The Moore court clearly stated that "[t]he government remains free to call as its first witness a law enforcement officer who is familiar with the pre-indictment investigation or was otherwise personally involved, where permissible under the Rules of Evidence and consistent with constitutional guarantees," and "[s]uch a witness may, for example, be able to provide relevant background information as to the investigation's duration and scope or the methods of surveillance, based on personal knowledge." (Id.) The court indicated that FBI Agent Sparks "could properly describe, based on his personal knowledge, how the gang investigation in this case was initiated, what law enforcement entities were involved, and what investigative techniques were used," but "he could not ... present lay opinion testimony about investigative techniques in general and opine on what generally works and what does not, as illustrated by informants who pled guilty" and could not "anticipate evidence that the government would hope to introduce at trial about the charged offenses or express an opinion, directly or indirectly, about the strength of that evidence or the credibility of any of the government's potential witnesses, including the cooperating co-conspirators." (Id. at 61.)

\section{Harmless Error}

Despite its harsh criticism of Agent Sparks's overview testimony, Moore held that it did not prejudice the defendants for several reasons. The testimony identified by the defendants as problematic on appeal was all confirmed by trial testimony. The defense was focused on cross-examining testifying co-conspirators and other government witnesses, and the trial judge instructed the jury at the conclusion of Sparks's testimony to disregard any opinions he offered. Most importantly, perhaps, there was overwhelming evidence of guilt.

\section{Lessons}

1. Moore is not the first appellate opinion to discuss the dangers of overview testimony. The fact that a number of courts have criticized such testimony should put prosecutors on notice that a conviction may be at risk if they utilize an overview witness, especially in jurisdictions where an appellate court has criticized the practice.

2. Moore provides defense counsel who share the Moore court's concern about the use of overview witnesses a summary of the dangers that can be cited in support of an objection to such testimony.

3. The use of an overview witness early in a case poses more problems than the use of a summary witness later in a case (although both uses pose risks), because late in a case the parties and the court are able to compare the summary witness's testimony with the evidence already presented and to object to variances or improper lay opinions about that evidence. Early in a case, it is more difficult to know whether the overview witness's testimony will be entirely consistent with evidence not yet presented and/or whether a lay opinion is supported by sufficient personal knowledge.

4. In sum, the prosecution, the defense, and the trial court share an interest in avoiding the use of overview witnesses, for as Moore observed, "[t]his court now having made clear the exacerbated 'obvious dangers' of the overview witness testifying about evidence yet to be admitted before the jury affords all parties clear direction to avoid unnecessary risks - for the prosecutor of an overturned conviction, for the defense of an unfair trial, and for the district court of having to retry a case." (Id. at 61.)

5. Forgoing the use of an overview witness ought not to leave government lawyers feeling that they will not have an adequate opportunity to explain complex cases. As Moore reminds, "this court's long-held view of the purpose of the opening statement to the jury, namely to allow the prosecutor the opportunity to provide the jury with an objective overview of the evidence that the government intends to introduce at trial, has long afforded the prosecutor the opportunity to do that for which the prosecutor improperly used FBI Agent Sparks.” (Id. (citations omitted).) $\square$ 